\title{
Maternal plasma prolidase, matrix metalloproteinases 1 and 13, and oxidative stress levels in pregnancies complicated by preterm premature rupture of the membranes and chorioamnionitis
}

\section{Preterm erken membran rüptürü ve koryoamnionitle komplike gebeliklerde maternal plazma prolidaz, matriks metalloproteinaz 1 ve 13, ve oksidatif stres seviyeleri}

\author{
Hatice Ender Soydinç ${ }^{1}$, Muhammet Erdal Sak ${ }^{1}$, Osman Evliyaoğlu ${ }^{2}$, Mehmet Sıddık Evsen $^{1}$, Abdulkadir Turgut ${ }^{1}$, \\ Ali Özler ${ }^{1}$, Hayrettin Tay', Talip Gül ${ }^{1}$ \\ 'Department of Gynecology and Obstetrics, Faculty of Medicine, Dicle University, Diyarbakur, Turkey \\ ${ }^{2}$ Department of Biochemistry, Faculty of Medicine, Dicle University, Diyarbakur, Turkey
}

\section{Abstract}

\begin{abstract}
Objective: This study aimed to investigate the role of various biochemical markers in preterm premature rupture of membranes (PPROM) and in prediction of chorioamnionitis in patients with PPROM.

Material and Methods: This case-control study included a total of 100 pregnant women at 26-34 gestational weeks. Of these women, 50 were healthy and 50 had PPROM. The biochemical markers in the maternal plasma including prolidase, matrix metalloproteinase (MMP) 1 and 13, total oxidative status (TOS), total antioxidant capacity (TAC), glutathione peroxidase (GPx), catalase (CAT), paraoxonase-1 (PON-1), tumor necrosis factor alpha (TNF- $\alpha$ ), and high sensitive C-reactive protein (hs$\mathrm{CRP}$ ) were assayed. These levels were compared between the PPROM and control groups and between women with or without chorioamnionitis in the PPROM group.
\end{abstract}

Results: Compared to the control group, the levels of prolidase, MMP13 , and TOS were significantly higher ( $\mathrm{p}$ values $<0.001,0.020$, and 0.035 , respectively) and those of TAC and PON-1 were significantly lower in the maternal plasma of the PPROM group ( $\mathrm{p}$ values $=0.012$ and $<0.001$, respectively). The plasma prolidase and TOS levels were significantly higher ( $p$ values $=0.033$ and 0.005 , respectively) and the plasma TAC and PON-1 levels were significantly lower in women with chorioamnionitis as compared with the corresponding values in women without chorioamnionitis in the PPROM group ( $p$ values $=0.041$ and 0.048 , respectively). The multivariate logistic regression analysis observed that prolidase, TAC, and PON-1 were important markers for the presence of PPROM and prolidase and TOS were important markers for predicting chorioamnionitis.

Conclusion: This study suggested that maternal plasma prolidase, TAC, and PON-1 may be useful for the diagnosis of PPROM, and prolidase and TOS may be used to predict chorioamnionitis in patients with PPROM. (J Turkish-German Gynecol Assoc 2012; 13: 172-7)

Key words: Preterm premature rupture of membranes, maternal plasma, prolidase, matrix metalloproteinase, oxidative stress

Received: 13 June, 2012

Accepted: 21 July, 2012

\section{Özet}

Amaç: Bu çalışmanın amacı çeşitli biokimyasal belirteçlerin preterm erken membran rüptürü (PEMR) ve PEMR olan hastalarda koryoamnioniti predikte etmedeki rollerini araştırmaktır.

Gereç ve Yöntemler: Bu vaka-kontrol çalışma, 26 ile 34 gebelik haftaları arasında 100 gebe kadını kapsadı. Bu gebe kadınların 50'si sağlıklı, 50'si PEMR'ne sahipti. Maternal plazmada, biokimyasal belirteçler olarak, prolidaz, matriks metalloproteinaz 1 ve 13 , total oksidatif status (TOS), total antioksidan kapasite (TAC), glutatyon peroksidaz (GPx), katalaz (CAT) ve paraoksonaz-1 (PON-1), tümör nekrozis faktör alfa (TNF- $\alpha$ ) ve yüksek sensitif C-reaktif protein (hs-CRP) test edildi. Biokimyasal belirteçlerin plazma düzeyleri, hem PEMR ve kontrol grubu arasında, hem de PEMR grubunda koryoamnionit gelişen ve gelişmeyen hastalar arasında karşılaştırıldı.

Bulgular: Kontrol grubuyla karşılaştırıldığında, PEMR olan hastalarda maternal plazma prolidaz, MMP-13 ve TOS düzeyleri anlamlı yüksek ( $p$ değeri; <0.001, 0.020, 0.035); TAC ve PON-1 düzeyleri anlamlı düşüktü (p değeri; $0.012,<0.001$ ). PEMR grubunda, koryoamnionit gelişen kadınlarda, koryoamnionit gelişmeyen kadınlardaki değerlerle karşılaştırıldığında plazma prolidaz ve TOS düzeyleri anlamlı yüksek ( $p$ değeri; 0.033, 0.005); TAC ve PON-1 anlamlı düşüktü (p değeri; $0.041,0.048$ ). Multivaryans lojistik regresyon analiz ile prolidaz, TAC ve PON-1'in PEMR'nün varlığı için; prolidaz ve TOS'un koryoamnioniti predikte etmek için önemli belirteçler oldukları bulundu.

Sonuç: Bu çalışma maternal plazma prolidaz, TAC ve PON-1'in PEMR'nün tanısında faydalı olabileceğini; prolidaz ve TOS'un PEMR olan hastalarda koryoamnionitin öngörülebilmesinde kullanılabileceğini gösterdi. (J Turkish-German Gynecol Assoc 2012; 13: 172-7)

Anahtar kelimeler: Preterm erken membran rüptürü, maternal plazma, prolidaz, matriks metalloproteinaz, oksidatif stres

Geliş Tarihi: 13 Haziran 2012

Kabul Tarihi: 21 Temmuz 2012 


\section{Introduction}

Premature rupture of membranes (PROM) is defined as the rupture of fetal membranes any time before the start of labor. If this rupture occurs before the thirty-seventh week of gestation, it is known as preterm premature rupture of membranes (PPROM). PPROM occurs in approximately $1 \%$ of all pregnancies and in $30 \%$ of all preterm deliveries (1). Lower socioeconomic level, lower maternal mass body index (BMI), smoking, history of preterm birth, urinary and genital tract infections, increase in membrane tensile strength due to excessive uterine distension as in polyhydramnios, vaginal bleeding at any stage of pregnancy, amniocentesis, and cerclage have been considered to be risk factors for PPROM (2). Although impaired collagen metabolism, increased oxidative stress, and choriodecidual inflammation or infections are suspected to be involved in its etiopathogenesis, its etiology has not yet been fully elucidated (3-5). PPROM can be diagnosed by the presence of amniotic fluid leakage from the external cervical ostium observed during sterile speculum examination. Although some pregnant women may complain of symptoms suggestive of PPROM, the examination findings might not support this diagnosis. In such cases, establishment of diagnosis can be challenging. In the treatment of PPROM, if there are no findings of labor, fetal distress, and chorioamnionitis, expectant management is preferred for the maturation of fetal lungs (6). Chorioamnionitis is an important infection, increasing both maternal and neonatal morbidity and mortality $(7,8)$. Therefore, it is important to detect subclinical intrauterine infection before the development of clinical chorioamnionitis. Although culture of fluid obtained by amniocentesis is a safe method for diagnosing intrauterine infection, due to its invasive nature several studies have aimed to develop noninvasive diagnostic tests (9).

In this study, our aim was to determine the importance of plasma markers in the prediction of PPROM and chorioamnionitis in pregnant women. To this end, we measured the prolidase, matrix metalloproteinase 1 and 13 (MMP1 and MMP13, respectively), total oxidative status (TOS), total antioxidant capacity (TAC), glutathione peroxidase (GPx), catalase (CAT), paraoxonase 1 (PON 1), tumor necrosis factor alpha (TNF- $\alpha$ ), and high sensitive C-reactive protein (hs-CRP) in the plasma of healthy pregnant women and pregnant women with PPROM.

\section{Material and Methods}

This prospective case-controlled study was conducted at the Dicle University Faculty of Medicine, Department of Gynecology and Obstetrics between January and December 2011. The study protocol was approved by Ethics Committee of our university. Informed written consents were obtained from all the pregnant women participating in the study.

This study included a total of 100 pregnant women at 26-34 weeks of gestation, of whom 50 were healthy (control group) and 50 had PPROM (PPROM group). Women with preeclampsia, placenta previa, ablatio placentae, polyhydramnios, multiple pregnancies, major fetal anomaly, diabetes mellitus, chronic systemic disease, and suspected PPROM were excluded from the study. PPROM was diagnosed by observing the accumulation of amniotic fluid in the posterior fornix during sterile speculum examination as well as by a positive nitrazine test. Routine laboratory examination for all patients included complete urinalysis, routine whole blood count, biochemical tests, as well as obstetric ultrasonography (US) examinations to determine the gestational age, major anomalies, amniotic fluid index, and number of fetuses. In the PPROM group, high-sensitive C-reactive protein (hs-CRP), cervicovaginal cultures and postpartum placental histopathological examination were performed.

The expectant management was applied to pregnant women in the PPROM group. All the women were given prophylactic antibiotic therapy (with ampicillin) as medical intervention. Also, standard antenatal corticosteroid therapy (with betamethasone) was administered for accelerating fetal lung maturation in pregnant women with PPROM before 32 weeks of gestation (1). The pregnancy was terminated with the development of fetal distress, active labor, and clinical chorioamnionitis.

The patients in the PPROM group were closely followed up for clinical infection indices such as fever, heart rate, vaginal discharge, uterine sensitivity, white blood cell count, and hsCRP levels. Chorioamnionitis was clinically diagnosed by 2 or more positive results among the following tests: uterine sensitivity and irritability, foul-smelling and purulent discharge, leukocytosis ( $>15000$ cells $/ \mathrm{mm}^{3}$ ), and maternal fever of $\geq 38^{\circ} \mathrm{C}$ during the hospitalization (10). Histologically, the diagnosis of chorioamnionitis was established by findings of acute inflammatory changes in the chorionic placenta and its membranes. However, funisitis was defined as detection of neutrophilic infiltration into the umbilical vessel wall and Wharton gel (11). In the PPROM group, participants with or without clinical and/ or histopathological chorioamnionitis were defined as chorioamnionitis (+) and (-), respectively.

Participants in the control group were pregnant women at 26-34 weeks of gestation who delivered at term and did not show any emergent complications of pregnancy during routine prenatal controls.

\section{Sampling}

We collected one blood sample from each patient on hospital admission prior to administration of steroids and antibiotics in the PPROM group and on routine pregnancy follow-up in the control group at the same time of gestation. Blood samples drawn from the antecubital vein were centrifuged at $3000 \mathrm{rpm}$ for 10 minutes, and plasma portions of the samples were stored at $-80^{\circ} \mathrm{C}$ until laboratory analysis.

\section{Biochemical analyses}

Enzymatic activity of prolidase, TAC, and TOS were analyzed as described previously (12). CAT and PON-1 activities were measured using the method of Aebi et al. (13) and spectrophotometrically by the modified Eckerson method, respectively (14). Enzyme-linked immunosorbent assay (ELISA) kits were used to measure the MMP1, MMP13 (Raybiotech Inc. USA), TNF- $\alpha$, and hs-CRP levels (Diasource Immunoassays S.A., Belgium). GPx activity was measured according to the method described by Kayabasi et al. (15). 
For the quantitative analysis of whole blood count and of routine biochemical parameters, an Abbott Cell Dyn 3700 Hematology Analyzer (Abbott Diagnostics, IL, USA), and a Roche/Hitachi P 800 module autoanalyzer (Roche Diagnostics, IN, USA), respectively, were used.

\section{Statistical Analysis}

Data were analyzed using the Microsoft Statistical Package for Social Sciences (SPSS) version 18.0 for Windows. The sample size was calculated with Cohen's power analysis method using effect size $d=0.8,80 \%$ power, alpha $=0.05$, and considering the results of previous studies (16).

The normality of distribution of data was tested using the Kolmogorov-Smirnov statistical method. Mann-Whitney $U$ and Student's $t$ tests were used for continuous variables, and the chi-square, Pearson's chi-square, and Fisher's exact tests were used for categorical variables. Logistic regression analyses were carried out to assess the correlations between these parameters and detect PPROM and chorioamnionitis in cases with PPROM. $\mathrm{P}<0.05$ was considered statistically significant.

\section{Results}

The study included 50 pregnant women with PPROM and 50 healthy pregnant women (control group). There were no signif- icant differences in the demographic parameters between both the groups (Table 1). In the PPROM group, all pregnant women received prophylactic antibiotic therapy. For those with age of gestation of $<32$ weeks, corticosteroid therapy was instituted to support fetal lung maturation. At the time of hospital admission, the mean time after membrane rupture was $1.93 \pm 0.37$ days. The mean time until the delivery after membrane rupture was $6.75 \pm 2.9$ days.

Cervicovaginal cultures were positive in 10 of the 50 (20\%) women, with Candida albicans in 6, Enterobacteriaceae in 3, and group B streptococci in 3. In the PPROM group, clinical chorioamnionitis developed in 7 (14\%) women. Indices of clinical chorioamnionitis, including increased CRP levels $(n=7$; $14 \%$ ), leukocytosis ( $n=12 ; 24 \%)$, fever $\geq 38^{\circ} \mathrm{C}(\mathrm{n}=7 ; 14 \%)$, foulsmelling vaginal discharge $(n=7 ; 14 \%)$, and uterine sensitivity $(n=3 ; 6 \%)$, were detected. Further, $13(26 \%)$ of the 50 pregnant women exhibited histological evidence of chorioamnionitis.

The maternal plasma levels of prolidase, MMP-1, MMP-13, TOS, TAC, PON-1, CAT, GPx, TNF- $\alpha$, and hs-CRP in both the groups are presented in Table 2. As compared with the control group, the prolidase, MMP-13, and TOS levels were significantly higher in the PPROM group, while the TAC and PON-1 levels were found significantly lower. The MMP-1, GPx, CAT, TNF- $\alpha$, and hsCRP levels did not differ significantly between groups (Table 2). Multivariate logistic regression analyses of statistically signifi-

Table 1. Demographic characteristics

\begin{tabular}{|c|c|c|c|}
\hline & $\begin{array}{c}\text { PPROM group } \\
\text { N (50) }\end{array}$ & $\begin{array}{c}\text { Control group } \\
\text { N (50) }\end{array}$ & $P$ value \\
\hline Maternal age (year) & $28.9 \pm 4.80$ & $29.2 \pm 6.80$ & 0.852 \\
\hline Abortion & $0.65 \pm 1.29$ & $0.37 \pm 0.89$ & 0.254 \\
\hline Gestational age (week in first evaluation) & $30.75 \pm 3.89$ & $31.10 \pm 3.94$ & 0.684 \\
\hline BMI $\left(\mathrm{kg} / \mathrm{m}^{2}\right)$ & $27.5 \pm 1.68$ & $27.8 \pm 1.65$ & 0.527 \\
\hline
\end{tabular}

Table 2. The maternal plasma levels of parameters

\begin{tabular}{|c|c|c|c|}
\hline Parameters & $\begin{array}{c}\text { PPROM group } \\
\text { N (50) }\end{array}$ & $\begin{array}{c}\text { Control group } \\
\text { N (50) }\end{array}$ & $P$ value \\
\hline Prolidase (U/L) & $793.2 \pm 141.6$ & $525.2 \pm 107.1$ & $<0.001$ \\
\hline MMP 1 (pg/mL) & $244.6 \pm 65.59$ & $220.8 \pm 48.26$ & 0.060 \\
\hline MMP $13(\mathrm{pg} / \mathrm{mL})$ & $380.8 \pm 122.1$ & $325.6 \pm 89.82$ & 0.020 \\
\hline TOS ( $\mu$ mol H2O2 Equiv./L) & $12.87 \pm 3.43$ & $11.55 \pm 2.03$ & 0.035 \\
\hline TAC (mmolTrolox Equiv./L) & $0.93 \pm 0.42$ & $1.17 \pm 0.41$ & 0.012 \\
\hline $\mathrm{GPx}(\mathrm{U} / \mathrm{mL})$ & $1.73 \pm 1.34$ & $2.14 \pm 1.57$ & 0.201 \\
\hline CAT (U/L) & $599.5 \pm 166.3$ & $646.8 \pm 150.7$ & 0.18 \\
\hline PON 1 (U/L) & $61.26 \pm 14.05$ & $98.84 \pm 36.41$ & $<0.001$ \\
\hline TNF- $\alpha(p g / m L)$ & $14.37 \pm 2.71$ & $14.88 \pm 5.08$ & 0.571 \\
\hline hs-CRP (mg/dL) & $0.78 \pm 0.52$ & $0.68 \pm 0.35$ & 0.328 \\
\hline
\end{tabular}


cant parameters revealed that the prolidase, TAC, and PON-1 levels were important predictors of PPROM (Table 3).

Comparison of the biochemical parameters of the women in the PPROM group with negative and positive cervicovaginal cultures revealed no significant differences. In the PPROM group, the prolidase and TOS levels were significantly higher while the TAC and PON-1 levels were significantly lower in women with chorioamnionitis when compared with the corresponding levels in women without signs of chorioamnionitis (Table 4). Furthermore, multivariate logistic regression analyses for these parameters were performed, and it was found that the plasma prolidase and TOS levels were important predictive markers of chorioamnionitis (Table 5).

\section{Discussion}

PPROM is an important obstetric problem whose etiopathogenesis has been suggested to involve factors such as impaired collagen metabolism, increased oxidative stress, choriodecidual inflammation, and/or infection. Fetal membranes are comprised of the amnion and chorion, which are both strong and flexible. These membranes consist of collagens and noncollagenous materials. Prolidase and MMPs are enzymes that play important roles in the metabolism of collagen. Also, PPROM has been suggested to be related to increased oxidative stress and infection and/or inflammation at the amniochorionic site. Therefore, we investigated the levels of the above-mentioned

Table 3. The multivariate logistic regression analysis of parameters related to PPROM

\begin{tabular}{|l|c|c|c|}
\hline Parameters & Beta-coefficient & P value & Odds ratio (95\% CI) \\
\hline Prolidase & 0.016 & $<0.001$ & $1.016(1.007-1.026)$ \\
\hline MMP 13 & 0.007 & 0.163 & $1.007(0.997-1.017)$ \\
\hline TOS & 0.136 & 0.461 & $1.146(0.798-1.646)$ \\
\hline TAC & -3.091 & 0.016 & $0.045(0.004-0.568)$ \\
\hline PON 1 & -0.067 & 0.006 & $0.935(0.891-0.981)$ \\
\hline $\begin{array}{l}\text { CI: confidence interval, PPROM: preterm premature rupture of membrane, MMP 13: matrix metalloproteinase 13, TOS: total oxidative status, TAC: total antioxidant } \\
\text { capacity, PON 1: paraoxonase 1 }\end{array}$
\end{tabular}

Table 4. The maternal plasma levels of parameters in pregnant women with and without chorioamnionitis in the PPROM group

\begin{tabular}{|c|c|c|c|}
\hline Parameters & $\begin{array}{c}\text { Chorioamnionitis (+) } \\
(\mathrm{N}: 13)\end{array}$ & $\begin{array}{c}\text { Chorioamnionitis (-) } \\
\text { (N:37) }\end{array}$ & $\begin{array}{c}\mathbf{P} \\
\text { value }\end{array}$ \\
\hline Prolidase (U/L) & $854.7 \pm 87.09$ & $754.6 \pm 151.4$ & 0.033 \\
\hline MMP 13 (pg/mL) & $387.2 \pm 138.8$ & $377.5 \pm 114.9$ & 0.970 \\
\hline TOS $\left(\mu \mathrm{mol} \mathrm{H}_{2} \mathrm{O}_{2}\right.$ Equiv./L) & $14.73 \pm 3.79$ & $11.90 \pm 2.83$ & 0.005 \\
\hline GPx (U/mL) & $1.67 \pm 1.16$ & $1.76 \pm 1.44$ & 0.862 \\
\hline CAT (U/L) & $552.6 \pm 177.5$ & $623.8 \pm 157.9$ & 0.220 \\
\hline PON 1 (U/L) & $54.26 \pm 13.56$ & $64.89 \pm 13.09$ & 0.048 \\
\hline TNF- $\alpha(p g / m L)$ & $14.82 \pm 3.31$ & $14.13 \pm 2.37$ & 0.665 \\
\hline
\end{tabular}

Table 5. The multivariate logistic regression analysis of parameters related to chorioamnionitis

\begin{tabular}{|l|c|c|c|}
\hline Parameters & Beta-coefficient & P value & Odds ratio (95\% CI) \\
\hline Prolidase & 0.007 & 0.049 & $1.007(1.002-1.013)$ \\
\hline TOS & 0.285 & 0.021 & $1.329(1.044-1.693)$ \\
\hline TAC & -2.017 & 0.064 & $0.133(0.016-1.127)$ \\
\hline PON 1 & -0.072 & 0.084 & $0.931(0.858-1.010)$ \\
\hline $\begin{array}{l}\text { CI: confidence interval, PPROM: preterm premature rupture of membrane, MMP 13: matrix metalloproteinase 13, TOS: total oxidative status, TAC: total antioxidant } \\
\text { capacity, PON 1: paraoxonase 1 }\end{array}$ \\
\hline
\end{tabular}


enzymes, oxidative stress, and inflammation in women with PPROM and in women who developed chorioamnionitis during the clinic follow-up in the PPROM group, assuming that increased or decreased levels of the above parameters would aid in the diagnosis of PPROM as well as in the prediction of chorioamnionitis. In this study, the levels of prolidase, MMP-1, and MMP-13, which play important roles in collagen metabolism; TOS, TAC, PON-1, CAT, and GPx as oxidative stress markers; and TNF- $\alpha$ and hs-CRP as inflammatory markers were analyzed in the maternal plasma of pregnant women with PPROM and in healthy pregnant women (controls). In patients with PPROM, while the levels of prolidase, MMP-13 and TOS were significantly higher, the TAC and PON-1 levels were lower as compared to the control group. While significantly increased levels of prolidase and TOS were found, the TAC and PON-1 levels were significantly decreased in patients with PPROM who subsequently developed chorioamnionitis.

Prolidase is a cytoplasmic enzyme that degrades imidopeptides containing C-terminal proline and hydroxyproline. Prolidase activity plays an important role in the production of collagen and other proteins with a proline content, and it is an indicator of increased collagen turnover $(17,18)$. Prolidase activity has been found to increase in diseases associated with collagen metabolism disorders as pathogenetic processes (19-21). Moreover, collagen metabolism disorder has been proposed as an etiopathogenetic factor for PPROM. Therefore, we investigated the prolidase activity in the plasma samples of pregnant women with PPROM. Prolidase activity was significantly increased in the PPROM group, and it was significantly higher in women with chorioamnionitis than in women without this condition. Moreover, multivariate regression analyses revealed that prolidase was a significant predictive marker for both PPROM and chorioamnionitis.

The amniochorionic extracellular matrix consists of intense connective tissue and is considerably resistant to proteases. Their physiological degradation requires involvement of specific proteases, namely, matrix metalloproteinases (MMPs). MMPs are released in an inactive form and inhibited by tissue-specific inhibitors of MMPs. Their activation has been demonstrated to be an important marker in PPROM (22-24). MMP-1, or collagenase I, and MMP-13, or collagenase III, are 2 members of the proteinase family found in the fetal membrane and amniotic fluid (24). In the present study, the relationship of these 2 enzymes with PPROM was investigated. Although higher plasma MMP-13 activities were detected in cases with PPROM, multivariate regression analysis revealed that the diagnostic value of MMP-13 activity was insignificant for PPROM. The MMP-1 levels did not differ significantly between the two groups.

Oxidative stress (OS) is defined as an imbalance between the production of reactive oxygen species and the protective capacity of antioxidants. Pregnancy is a state causing oxidative stress due to increased metabolic activity and decreased antioxidant capacity (25). The oxidative stress induced in the intrauterine compartment reflects in the maternal circulation (20). In many studies, significant increase in the oxidative stress and decrease in antioxidant capacity have been reported in conditions with adverse outcomes in pregnancy, such as preeclampsia, fetal growth restriction, and preterm birth, when compared with the levels in normal pregnancies $(26,27)$. Few studies have investigated the association between PPROM and oxidative stress. In our study, we investigated the antioxidant markers CAT, PON-1, GPx, and TAC and the oxidative marker TOS. In the PPROM group, as well as in the subset of this group who developed chorioamnionitis, the TOS levels were higher and the TAC and PON-1 levels were lower as compared to the control and chorioamnionitis (-) subset, respectively. There was no significant difference in the CAT and GPx level between the groups. The TAC and PON-1 levels were found to be significant predictive markers for PPROM, whereas the TOS level was revealed to be significant as a predictive marker of chorioamnionitis.

In pregnancy, the production of anti-inflammatory and proinflammatory cytokines are balanced. Anti-inflammatory cytokines are dominant during the early stages of pregnancy, and the level of proinflammatory cytokines increases as the pregnancy progresses and during its advanced stages. Even labor is said to be induced as a result of an inflammatory process. Increase in the proinflammatory cytokines has been reported in the etiology of PPROM (28). Increased levels of IL-6 and IL-8 in patients with PPROM have further supported these findings $(9,29)$. In our study, comparison of the TNF- $\alpha$ and hs-CRP levels in both the groups as well as in the chorioamnionitis (+) and (-) groups revealed no significant differences.

One of the theories in the pathogenesis of PPROM is intrauterine infection (1). Intrauterine infection can be effectively diagnosed by assessments such as gram stain, culture, and by evaluation of glucose and interleukin- 6 levels of amniotic fluid obtained by amniocentesis (30). The studies demonstrated that the prophylactic antimicrobial therapy has beneficial effects, including prolongation of pregnancy and prevention of chorioamnionitis and neonatal sepsis. The studies were performed to investigate prolonged pregnancy with prophylactic antimicrobial therapy, considering infection as the pathogenesis of PPROM (31, 32). These studies reported that antimicrobial treatment significantly delayed delivery in pregnant women with PPROM. Since amniocentesis is an invasive method, no amniocentesis was performed in this study; however, all pregnant women with PPROM received prophylactic antimicrobial therapy with ampicillin. Clinical chorioamnionitis developed in 7 (14\%) women, and the mean time until delivery was found to be $6.75 \pm 2.9$ days.

\section{Conclusion}

We determined that the maternal plasma levels of prolidase, TAC, and PON-1 are significant predictive factors for PPROM and that the prolidase and TOS levels are a significant predictive factor for chorioamnionitis. Further study is required to determine whether or not these markers can be used in noninvasive tests as predictors for both PPROM and subsequent chorioamnionitis.

\section{Acknowledgement}

This study was supported by Scientific Research and Project Coordinator (DUBAB, 10-TF-57) in Dicle University. 


\section{Conflict of interest}

No conflict of interest was declared by the authors.

\section{References}

1. Gibbs RS, Karlan BY, Haney AF, Nygaard IE. Premature Rupture of the Membranes. In: Gibbs RS, editor. Danforth's Obstetrics and Gynecology. Lippincott Williams \& Wilkins; 2008; 186-97.

2. Mercer B, Milluzzi C, Collin M. Periviable birth at 20 to 26 weeks of gestation: proximate causes, previous obstetric history and recurrence risk. Am J Obstet Gynecol 2005; 193: 1175-80. [CrossRef]

3. Parry S, Strauss III JF. Premature rupture of the fetal membranes. N Engl J Med 1998; 338: 663-70. [CrossRef]

4. Mercer BM, Goldenberg RL, Meis PJ, Moawad AH, Shellhaas C, Das A, et al. The Preterm Prediction Study: prediction of preterm premature rupture of membranes through clinical findings and ancillary testing. The National Institute of Child Health and Human Development Maternal- Fetal Medicine Units Network. Am J Obstet Gynecol 2000; 183: 738-45. [CrossRef]

5. Woods JR Jr. Reactive oxygen species and preterm premature rupture of membranes. Placenta 2001; 22: 38-44.

6. ACOG Committee on Practice Bulletins-Obstetrics. ACOG Practice Bulletin No. 80: premature rupture of membranes. Clinical management guidelines for obstetrician-gynecologists. Obstet Gynecol 2007; 109: 1007-19.

7. Popowski T, Goffinet F, Batteux F, Maillard F, Kayem G. Prediction of maternofetal infection in preterm premature rupture of membranes: serum maternal markers. Gynecol Obstet Fertil 2011; 39: 302-8. [CrossRef]

8. Waters TP, Mercer BM. The management of preterm premature rupture of the membranes near the limit of fetal viability. Am J Obstet Gynecol 2009; 201: 230-40. [CrossRef]

9. Cobo T, Palacio M, Martínez-Terrón M, Navarro-Sastre A, Bosch $\mathrm{J}$, Filella X, Gratacós E. Clinical and inflammatory markers in amniotic fluid as predictors of adverse outcomes in preterm premature rupture of membranes. Am J Obstet Gynecol 2011; 205: 126. e1-8.

10. Assi F, Fruscio R, Bonardi C, Ghidini A, Allavena P, Mantovani A, et al. Pentraxin 3 in plasma and vaginal fluid in women with preterm delivery. BJOG 2007; 114: 143-7. [CrossRef]

11. Kaplan C, Lowell DM, Salafia C. College of American Pathologists Conference XIX on the Examination of the Placenta: report of the Working Group on the Definition of Structural Changes Associated with Abnormal Function in the Maternal/Fetal/Placental Unit in the Second and Third Trimesters. Arch Pathol Lab Med 1991; 115: 709-16.

12. Uzar E, Tamam Y, Evliyaoglu O, Tuzcu A, Beyaz C, Acar A, et al. Serum prolidase activity and oxidative status in patients with diabetic neuropathy. Neurol Sci 2011; 33: 875-80. [CrossRef]

13. Aebi H. Catalase in vitro. Methods Enzymol. 1984; 105: 121-6. [CrossRef]

14. Eckerson HW, Wyte CM, La Du BN. The human serum paraoxonase/arylesterase polymorphism. Am J Hum Genet 1983; 35: 1126-38.

15. Kayabasi H, Sit D, Atay AE, Yilmaz Z, Kadiroglu AK, Yilmaz ME. Parameters of oxidative stress and echocardiographic indexes in patients on dialysis therapy. Ren Fail 2010; 32: 328-34. [CrossRef]

16. Cohen, J. Statistical Power Analysis for the Behavioral Sciences.
New York: Academic Press 1977; 32: 75-107.

17. Muszynska A, Pałka J, Gorodkiewicz E. The mechanism of daunorubicin induced inhibition of prolidase activity in human skin fibroblasts and its implication to impaired collagen biosynthesis. Exp Toxicol Pathol 2000; 52: 149-55. [CrossRef]

18. Emmerson KS, Phang JM. Hydrolysis of proline dipeptides completely fulfills the proline requirement in a proline-auxotropic Chinese hamster ovary cell line. J Nutr 1993; 123: 909-14.

19. Brosset B, Myara I, Fabre M, Lemonnier A. Plasma prolidase and prolinase activity in alcoholic liver disease. Clin Chim Acta 1988; 175: 291-5. [CrossRef]

20. Ipcioglu OM, Ozcan O, Gultepe M, Deniz O, Akgul EO. Prolidase activity in serum and pleural fluids in patients with tuberculous pleural effusion [correction of effussion]. Clin Biochem 2008; 41: 670-5. [CrossRef]

21. Toy H, Camuzcuoglu H, Arioz DT, Kurt S, Celik H, Aksoy N. Serum prolidase activity and oxidative stress markers in pregnancies with intrauterine growth restricted infants. J Obstet Gynaecol Res 2009; 35: 1047-53. [CrossRef]

22. Fortunato SJ, Menon R, Lombardi SJ. Collagenolytic enzymes (gelatinases) and their inhibitors in human amniochorionic membrane. Am J Obstet Gynecol 1997; 177: 731-41. [CrossRef]

23. Fortunato SJ, Menon R, Lombardi SJ. Amniochorion gelatinasegelatinase inhibitor imbalance in vitro: A possible infectious pathway to rupture. Obstet Gynecol 2000; 95: 240-4. [CrossRef]

24. Fortunato SJ, LaFleur B, Menon R. Collagenase-3 (MMP-13) in fetal membranes and amniotic fluid during pregnancy. Am J Reprod Immunol 2003; 49: 120-5. [CrossRef]

25. Wisdom SJ, Wilson R, McKillop JH, Walker JJ. Antioxidant systems in normal pregnancy and in pregnancy-induced hypertension. Am J Obstet Gynecol 1991; 165: 1701-4.

26. Myatt L, Cui X. Oxidative stress in the placenta. Histochem Cell Biol 2004; 122: 369-82. [CrossRef]

27. Takagi Y, Nikaido T, Toki T, Kita N, Kanai M, Ashida T, et al. Levels of oxidative stress and redox-related molecules in the placenta in preeclampsia and fetal growth restriction. Virchows Arch 2004; 44: 49-55. [CrossRef]

28. Orsi NM, Tribe RM. Cytokine networks and the regulation of uterine function in pregnancy and parturition. J Neuroendocrinol 2008; 20: 462-9. [CrossRef]

29. Polettini J, Peraçoli JC, Candeias JM, Araújo Júnior JP, Silva MG. Inflammatory cytokine mRNA detection by real time PCR in chorioamniotic membranes from pregnant women with preterm premature rupture of membranes. Eur J Obstet Gynecol Reprod Biol 2009; 144: 27-31. [CrossRef]

30. Cunningham FG, Leveno KJ, Bloom SL, Hauth JC, Rouse DJ, Spong CY. Preterm Birth. In: Cunningham FG, editor. Williams Obstetrics 23. edition. The McGraw-Hill Companies; 2010; 804-32.

31. Mercer BM, Arheart KL. Antimicrobial therapy in expectant management of preterm premature rupture of the membranes. Lancet 1995; 346: 1271-9. [CrossRef]

32. Ercan CM, Aydoğan U, Karasahin KM, Alanbay I, Başer I. Prolonged usage of intravaginal clindamycin cream combined with ampicillin for the management of PPROM - a case report. J TurkishGerman Gynecol Assoc 2011; 12: 124-6. [CrossRef] 